\title{
Restoring Civic Values to the News Media Ecology
}

The emergence of converged digital media platforms has seen a proliferation of new services, but also a disruption to value chains and business models, especially in a small, highly deregulated media market like New Zealand's. Although consumer choice has expanded in some respects (e.g. subscriber video on demand via smart tablets), this does not fundamentally alter the information needs of citizens if they are to participate in a democratic society. Although digital media also provide spaces for citizen journalism and informed blogging, these complement, rather than replace, mainstream news production.

The Civics and Media Project workshops identified several trends in the news sector which suggest that, on the current trajectory, the news media will struggle to meet the future needs of civil society. The pressure to reduce costs and optimise commercial performance has intensified as audience and revenues are fragmented across a wider range of platforms. This has been exacerbated by the inroads made by financial institutions and investment funds into media company ownership (known as financialisation) and the concomitant prioritisation of overseas shareholder demand for capital value/share performance over traditional journalistic values (Ellis, 2014). The result has been substantial cuts in news budgets and journalist redundancies and casualisation across almost all commercial news media (Myllylahti, 2015). Newsrooms have been consolidated across platforms (e.g. Mediaworks' Newshub and NZME's Newsroom models) which offer efficiencies but often reduced capacity. At the same time, the reluctance to invest in content which carries commercial risk or opportunity costs has seen in-depth

Gavin Ellis is a senior lecturer at the University of Auckland and a former editor-in-chief of the New Zealand Herald. He served as chair of the Media Freedom Committee, and was recipient of the 2005 Commonwealth Astor Award for services to press freedom. Peter Thompson is a senior lecturer at Victoria University of Wellington. He is a founding editor of the Political Economy of Communication Journal and is currently chair of the Coalition for Better Broadcasting.

investigation and analysis sacrificed for cheaper, more populist content which increases profit margins.

In response to the somewhat pessimistic diagnosis of the first Civics and Media workshop, the second set out some challenges for changing the trajectory, while the third identified suggestions for the kind of future policy frameworks, market settings and funding models needed to foster 'Big J' journalism aligned to citizen engagement. The third workshop set out three pillars to support this, as well as a funding proposal. The remainder of this article will discuss these in turn.

\section{Advocacy}

Renewed unity among the media is needed in order to promote the worth of journalism to schools and to the public, to advocate the new forms of funding we discuss later, to make the best use of significant journalism, and to promote a meaningful public sphere. Whereas the newspaper industry and broadcasters used to have a clear sense of civic mission, with strong industry and labour associations as their advocates (e.g. the Newspaper Publishers' Association and the New Zealand Press Association), the voices are now corporate, competitive and often adversarial. The need is for a structure to promote the rediscovery of a collective sense of journalistic mission. Defining 'the public interest' is notoriously difficult (Scruton, 2007, p.569) and this has led to 
often complex interpretations in relation to media (McQuail, 1992, p.3; Thompson, 2012, p.98). This has allowed the media sometimes to conflate the public interest with their own commercial interests. However, they do have the potential to cooperate for the greater good.

\section{Standards}

The second pillar identified was standards. There was recognition that the regulatory environment needed to be updated to take account of convergence, but without compromises to the protection of the public interest. At present, several statutory and industry bodies co-exist, including the New Zealand Press Council, the Online Media Standards Authority and the Broadcasting Standards Authority,
Culture and Heritage and Ministry of Economic Development, 2008), while the Law Commission's comprehensive 2013 The News Media Meets 'New Media' report (Law Commission, 2013) was largely ignored by the National-led government (and found little favour with the newspaper industry). The new regulatory review is therefore indicative of the extent to which the continuing absence of regulatory coherence in the media sector has been identified as an impediment to continued market growth, not least because of the government's vision of a technology-driven economy and its substantial investment in ultrafast broadband roll-out (Thompson, 2014, pp.146-56).

The self-regulating Press Council
... Labour's 2003-08 attempt to restructure Television New Zealand and give it a dual public service and commercial remit is widely regarded as a policy failure ...

all of which operate according to rather different principles and with different forms of intervention or sanction.

A green paper on the implications of convergence for regulatory arrangements - and a parallel discussion paper by the Ministry for Culture and Heritage on content regulation - were launched in August 2015 by the minister of communications, Amy Adams. The new initiative makes some useful diagnoses of regulatory gaps, but it remains unclear how far the government would be willing to contemplate a significant overhaul of existing arrangements. The government's track record on regulatory change suggests an ideological preference for minimising state intervention and a default 'wait and see' approach (often advocated by the Ministry of Business, Innovation and Employment) in the face of technical and market uncertainty. For example, the wide-ranging Digital Broadcasting: review of regulation (initiated under Labour) was terminated in 2009 (Ministry for takes a lay approach to its decisions, which carry no financial sanction, while the statutory Broadcasting Standards Authority has a quasi-judicial approach arising from its ability to impose financial penalties. The newspaper industry feared that regulatory amalgamation could lead away from self-regulation to a statutory authority and toward a more punitive system than the Press Council imposes, requiring newspapers to publish decisions that find against them. Broadcasters, meanwhile, would embrace a change if it took them from a statutory environment into self-regulation (and, indeed, that is part of the strategic agenda underpinning the establishment of the Online Media Standards Authority).

The Advertising Standards Authority, meanwhile, has a role in regulating advertising content across all platforms. It is an industry-based self-regulating body (albeit with public representation) which operates within a legal framework provided by a number of acts and regulations that permit it to consider, according to its complaints procedure, 'complaints about any advertisement in any medium' (see Advertising Standards Authority, n.d.).

It is important to differentiate between self-regulation and self-serving regulation. The need is for a consistent regulatory framework that serves the public interest rather than the commercial interests of media organisations. Although industry input into regulatory arrangements is important, the board of such a body would require a significant majority of independent lay members to prevent 'capture'. The complexity of technological convergence drives the call for change, even if recent experiences in the United Kingdom and other countries show that media regulatory reform is a minefield.

\section{Collaboration}

Reductions in the ranks of mainstream newsrooms have been paralleled by rapid growth in the numbers of individuals and groups contributing to civil dialogue in the digital environment, and in the capacity of tertiary faculties to produce journalism across all media. In other words, the ability to produce democratically significant journalism has not disappeared; rather, the willingness and drive to do it has dissipated.

One suggestion that emerged from the workshops was a return to some form of public service charter framework to rekindle a sense of civic mission in the media sector. Radio New Zealand still has a charter, of course, but Labour's 200308 attempt to restructure Television New Zealand and give it a dual public service and commercial remit is widely regarded as a policy failure (Thompson, 2011a), which would make returning to such a model politically unattractive. Expanding the remit of Radio New Zealand to include television as well as radio and online services may be feasible, but this would require public funding and an amenable government. The presence of a strong public service-oriented media operator (akin to the BBC or Australia's $\mathrm{ABC})$ in the centre of the media ecology would ensure the provision of genres under-supplied by the market, and also help anchor content standards and 
promote competition for quality, not just eyeballs or ratings.

However,engendering civicresponsibility among commercial operators in the contemporary market environment would be difficult. Financialisation, convergence and competition for fragmenting revenues and audience share have not been conducive to collaboration among news institutions. Nevertheless, the professional integrity and civic commitment of most journalists and news workers remains intact. Indeed, news professionals havebacked recent investigative, public interest ventures such as the Public Eyes project and the Scoop Foundation. The problem such initiatives face is that to reengage the wider public, they need funding and distribution platforms commensurate with their professional aspirations.

The Civics and Media workshops identified a need for 'Big J' journalism, entailing collaboration between not only existing media organisations - with strong recognition of the role that Radio New Zealand plays - but also journalism schools, faculties, freelancers and civic-oriented bloggers. It called for a media summit at which each of these parties could be asked to commit to a joint initiative to restore public service journalism. However, the grim reality for mainstream media is that their owners have different financial priorities. The key issue becomes one of how to fund 'Big J' journalism.

\section{Funding}

Funding options for public interest journalism was another key theme discussed in the Civics and Media workshops. Historically, non-commercial news media have been funded through licence fees, direct subsidies or contestable funding. All of these depend on the policy settings of the government, which currently prioritises funding content rather than institutions in the digital environment. Consequently, the budgets of Radio New Zealand and Māori Television have been frozen, the TVNZ charter abolished and the commercialfree channel TVNZ7 shut down. NZ On Air's Platinum Fund is permitted to fund current affairs television, and there have been appeals from the print news sector to expand the range of content and media eligible for such subsidies.
However, the contestable model's lack of vertical integration is a key weakness, because commercial commissioners and schedulers can effectively veto content not deemed commercially attractive.

A potential solution was proposed in workshop three in the form of a marginal levy on media services across the value chain (including telecommunications, subscription providers, advertising and audiovisual retail goods). The Coalition for Better Broadcasting has estimated that a marginal levy of $1 \%$ across the entire media value chain (including broadcasting, telecommunications and audiovisual retail) could raise up to $\$ 160$ million per annum (Coalition for Better Broadcasting, 2015). Even half of in the EU (France, Spain and Turkey all have variants - see Europa, 2010; Semova, 2010; Thompson, 2005), and the mechanism offers some useful structural and normative characteristics (Coalition for Better Broadcasting, 2015; Thompson, 2005; Thompson, 2011b):

- Given that a range of media services and products across the value chain (including distribution services and reception devices) collectively contribute to market failure, the levy mechanism leaves no commercial medium as a 'free rider' and would include tax-avoiding operations like offshore subscriber services, search engines and social media (e.g. Netflix, Google, Facebook).

\section{The civic and democratic role of media - broadly defined and coloured by the certain knowledge that there will be new forms and technologies that we have not anticipated - is unchanged.}

that would be sufficient to significantly redress many of the market failures in the current media ecology. Space precludes a fuller discussion, but, hypothetically, if half of that fund were allocated to extending the platforms and range of services of Radio New Zealand and Māori Television, the other half could be made available through NZ On Air to expand the range of contestable content. The new mechanism could include a platformneutral contestable fund devoted to public interest journalism and current affairs projects, for which existing news media and independent journalists and news websites could be eligible. Meanwhile, the extended services of Radio New Zealand and Māori Television would ensure that there were non-commercial platforms able and willing to carry content the commercial media deemed unattractive, thereby vertically integrating the contestable funds.

Like any public funding proposal, the levy model would have its critics, but similar models have been implemented
- Insofar as the fund would not require annual budget allocations from the government consolidated fund, it is fiscally neutral.

- It would be hypothecated and therefore insulated from interministerial budget wrangling as well as periodic changes in administration. It would also be directly linked to overall sector revenues and thus insulated from inflation.

- The levied media sectors would be able to pass on most costs to consumers, so their profit margins would not be significantly affected. Advertising revenue could be more complicated here, but exceptions could be made (e.g. for low-income media), while media relying on domestic advertising would likely be eligible for the new fund.

- Consumers would pay only a small amount (e.g. a $\$ 50$ phone bill or video-on-demand subscription would incur a levy of just 50 cents) 
and so contribute in proportion to their media consumption.

\section{Conclusion}

The civic and democratic role of media - broadly defined and coloured by the certain knowledge that there will be new forms and technologies that we have not anticipated - is unchanged. Whatever their form, news media will continue to be a means by which large audiences will be provided with common information on which to base individual opinions and collective decisions.

What has changed is the media ecology, which has been destabilised by disruptive technologies and rapacious financial interests. As Al Gore said of Earth's ecosystem, 'The planet is in distress and all of the attention is on Paris Hilton.' The Civics and Media Project represented a call to refocus attention on the positive contribution journalism could - and should - make to society. Despite the current challenges, there was a sense of optimism in its deliberations. A way forward was identified, but securing the vision will need commitment from policy makers and practitioners.

1 Interviewed in the British newspaper the Sun, 18 June 2007.

\section{References}

Advertising Standards Authority (n.d.) 'Complaints procedure', retrieved from http://www.asa.co.nz/complaints/complaints-process/

Coalition for Better Broadcasting (2015) Public Service Media Funding Framework: exploratory proposal, prepared by P.A. Thompson, Victoria University of Wellington, August

Ellis, G. (2014) Trust Ownership and the Future of News: media moguls and white knights, Basingstoke: Palgrave Macmillan

Europa (2010) 'State aid: commission approves long-term funding mechanism for France Télévisions', press release, 20 July, IP/10/979, retrieved from http://europa.eu/rapid/press-release_IP-10-979_ en.htm?locale $=\mathrm{nl}$

Law Commission (2013) The News Media Meets 'New Media': rights, responsibilities and regulation in the digital age, report 128 , Wellington: Law Commission, retrieved from http://r128. publications. lawcom.govt.nz

Ministry for Culture and Heritage (2015) Content Regulation in a Converged World, Wellington: Ministry for Culture and Heritage, retrieved from http://www.mch.govt.nz/sites/default/files/ContentRegulation-in-a-Converged-World-Discussion-Document-2015-08-25. pdf

Ministry for Culture and Heritage and Ministry of Economic Development (2008) Digital Broadcasting: review of regulation, Wellington: New Zealand Government, http://www.mch.govt.nz/research-publications/ our-research-reports/digital-broadcasting-review-regulation-january2008

McQuail, D. (1992) Media Performance: mass communication and the public interest, London: Sage

Myllylahti, M. (2015) JMAD New Zealand Media Ownership Report 2015, Auckland: AUT University, retrieved from http://www.aut.ac.nz/ study-at-aut/study-areas/communications/media-networks/journalism,-media-and-democracy-research-centre/journalists-and-projects

Scruton, R. (2007) The Palgrave Macmillan Dictionary of Political Thought, Basingstoke: Palgrave Macmillan

Semova, D.J. (2010) 'Financing public media in Spain: new strategies',

International Journal on Media Management, 12, pp.141-57

Thompson, P.A. (2005) 'Star Wars: The Empire Strikes Out? New developments in NZ current affairs and the competition for the prime time TV audience', New Zealand Political Review, 14 (1), Autumn, pp.44-9

Thompson, P.A. (2011a) 'Neoliberalism and the political economies of public television policy in New Zealand', Australian Journal of Communication, 38 (3), pp.1-16

Thompson, P.A. (2011b) 'Show me the money: funding possibilities for public television in New Zealand', paper presented at the 2011 SPADA conference, 10-11 November, Auckland, retrieved from http:// www.victoria.ac.nz/seftms/about/staff/peter-thompson/Show_Me_the Money_Thompson-SPADA_2011.pdf

Thompson, P.A. (2012) 'Last chance to see?', in M. Hirst, S. Phelan and V. Rupar (eds), Scooped: the politics and power of journalism in Aotearoa New Zealand, Auckland: AUT Media/JMAD

Thompson, P.A. (2014) 'Wired-up or wind-up? The political economy of broadband policy in New Zealand/Aotearoa', Media International Australia, 151 (1), pp.146-56

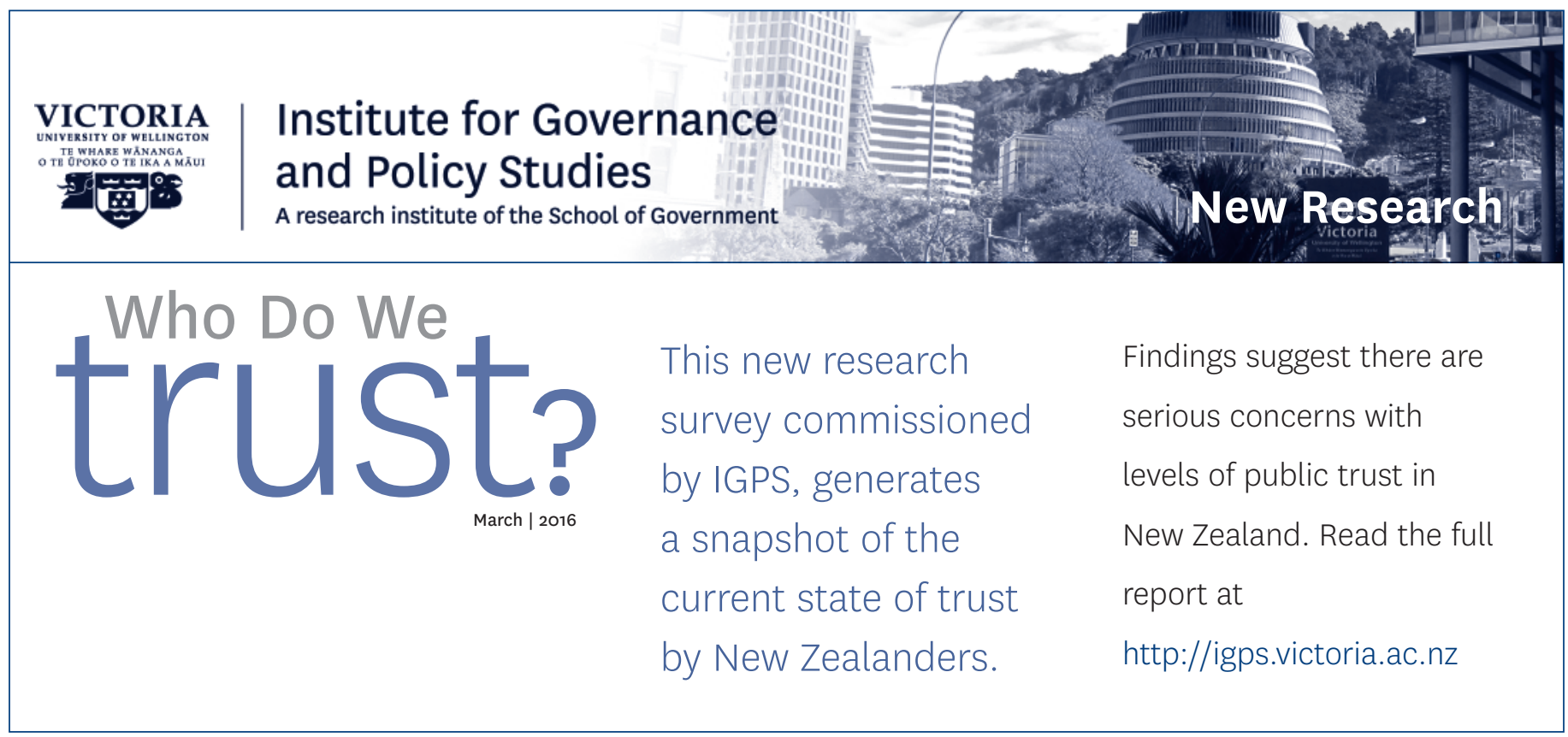

